\title{
Fatty acid synthesis in human testis incubated with $\left[1-{ }^{14} \mathrm{C}\right]$ acetate
}

\author{
J. G. Coniglio, W. M. Grogan, Jr* and R. K. Rhamy \\ Department of Biochemistry and Division of Urology, Department of Surgery, \\ Vanderbilt University School of Medicine, Nashville, Tennessee 37232, U.S.A.
}

The lipid composition of human testes obtained at orchidectomy or at autopsy has been described (Coniglio, Grogan \& Rhamy, 1974, 1975), but it is not known whether these lipids have their origin in lipids transported by the blood and/or are synthesized by testicular tissue itself. The testicular synthesis of palmitic and stearic acids in vitro from $\left[1-{ }^{14} \mathrm{C}\right]$ acetate was demonstrated by Hall, Nishizawa \& Eik-Nes (1963). Rat testicular tissue also has the ability to synthesize fatty acids de novo (Whorton \& Coniglio, 1975) and to convert others into longer chains (Bridges \& Coniglio, 1970a; Coniglio, Zseltvay \& Whorton, 1971). Fatty acids synthesized by rat testes are incorporated into complex lipids of the testes (Evans, Zseltvay, Whorton \& Coniglio, 1971).

There are important differences in fatty acid composition between rat and human testicular tissue (Coniglio et al., 1974) and in the present study slices of human testes were used to determine the lipogenic capability of the tissue.

\section{Methods}

Testes were placed directly into ice after removal at orchidectomy from patients, aged 57-86 years, with prostatic cancer. The testes themselves were not affected by disease. The tissue was freed of extraneous material and the tunica albuginea was removed. Approximately $1 \mathrm{~g}$ tissue was sliced into 4 to 6 pieces and incubated in air for $3 \mathrm{~h}$ in a solution of $0.2 \mathrm{ml}$ of an aqueous solution containing $4 \mu \mathrm{Ci}(0.2 \mathrm{mg})\left[1-{ }^{14} \mathrm{C}\right]$ sodium acetate (New England Nuclear Corporation, Boston, Mass.), $0.5 \mathrm{ml}$ $1.0 \mathrm{M}$-sodium phosphate buffer ( $\mathrm{pH} 7 \cdot 4$ ) and $1.3 \mathrm{ml} 10 \mathrm{mM}$-glucose made up in distilled water to a total volume of $2.6 \mathrm{ml}$. Incubations were terminated by addition of $\mathrm{KOH}$ to samples which were to be hydrolysed for subsequent isolation of total fatty acids or by pouring the medium into chloroform: methanol $(2: 1 \mathrm{v} / \mathrm{v})$ for samples from which the total lipids were to be extracted. The procedures for extraction and separation of lipids, hydrolysis of tissues and lipids, extraction of fatty acids, gas chromatography and radio-gas chromatography were those described previously (Bridges \& Coniglio, 1970a,b). Radio-gas chromatography was usually performed on non-hydrogenated and hydrogenated samples. Hydrogenation was by the method of Farquhar, Insull, Rosen, Stoffel \& Ahrens (1959). Radioactivity determinations of isolated lipids and fatty acids were made in a liquid scintillation spectrometer operating at $80 \%$ efficiency. Corrections for quenching were made when required.

Material for histology was fixed in Bouin's fluid. Sections $6 \mu \mathrm{m}$ thick were prepared, stained with periodic acid-Schiff and counterstained with Wright's iron-haematoxylin. Spermatogenesis was assessed on a scale from zero (absence of spermatogenesis) to $4+$ (that of normal adult male) after examination of a series of sections. Since there was no discernible maturation arrest and no discernible pathology, only the aspect of the presence or absence of spermatogenesis was evaluated and an estimation made of the quality.

\section{Results and discussion}

The total incorporation of ${ }^{14} \mathrm{C}$ from $\left[1-{ }^{14} \mathrm{C}\right]$ acetate into the total fatty acids of 23 samples was $3.7 \pm 0.22 \%$ (S.E.M.) of the substrate per $\mathrm{g}$ tissue. There was no consistent detectable variation with age or with the spermatogenic rating of the tissue.

* Present address: Department of Biochemistry, Medical College of Virginia, Virginia Commonwealth University, MCV Station, Richmond, Virginia 23298, U.S.A. 
Table 1. Incorporation of ${ }^{14} \mathrm{C}$ into individual fatty acids and into hydrogenated fatty acids of slices of human testis incubated with $\left[1-{ }^{14} \mathrm{C}\right]$ acetate

\begin{tabular}{|c|c|c|c|}
\hline \multicolumn{2}{|c|}{ Non-hydrogenated } & \multicolumn{2}{|c|}{ Hydrogenated } \\
\hline Fatty acid* & $\%$ of ${ }^{14} \mathrm{C}$ incorporated $\dagger$ & Fatty acid* & $\%$ of ${ }^{14} \mathrm{C}$ incorporated $\ddagger$ \\
\hline $\begin{array}{r}<14: 0 \\
14: 0 \\
16: 0 \\
16: 1 \\
18: 0 \\
18: 1 \\
18: 2 \\
20: 0 \\
20: 1 \\
20: 2 \\
20: 3 \\
20: 4 \\
22: 2,22: 3 \\
22: 4 \\
22: 5 \\
22: 6 \\
>22: 6\end{array}$ & $\begin{array}{r}5.1 \pm 0.3 \\
8.4 \pm 0.7 \\
16.5 \pm 1.5 \\
1.3 \pm 0.1 \\
5.8 \pm 0.4 \\
8.8 \pm 0.7 \\
2.4 \pm 0.3 \\
2.4 \pm 0.5 \\
3.9 \pm 0.4 \\
3.1 \pm 0.3 \\
14.9 \pm 1.1 \\
3.1 \pm 0.3 \\
6.8 \pm 1.6 \\
11.5 \pm 1.7 \\
2.1 \pm 0.4 \\
0.8 \pm 0.2 \\
2.1 \pm 0.5\end{array}$ & $\begin{array}{r}<14: 0 \\
14: 0 \\
16: 0 \\
18: 0 \\
20: 0 \\
22: 0 \\
24: 0\end{array}$ & $\begin{array}{r}6.1 \pm 0.7 \\
7.1 \pm 0.4 \\
16.6 \pm 0.7 \\
17.1 \pm 0.7 \\
29.6 \pm 1.6 \\
20.2 \pm 1.4 \\
3.1 \pm 0.6\end{array}$ \\
\hline
\end{tabular}

* No. of carbon atoms: no. of double bonds per molecule.

+ Mean \pm S.E.M. of 29 samples.

$\ddagger$ Mean \pm S.E.M. of 23 samples.

The distribution of radioactivity in individual fatty acids of the incubated testes and in hydrogenated derivatives is given in Table 1 . The largest amount of ${ }^{14} \mathrm{C}$ was in the 20 -carbon fatty acids, followed by the 22-carbon, the 18-carbon and 16-carbon acids. Significant amounts of ${ }^{14} \mathrm{C}(3 \%$ of the total) were also present in 24-carbon fatty acids. The radioactivity in the fraction designated as $<14: 0$ was mostly in 12:0. The only statistically significant difference $(P<0.01)$ with age was a lower incorporation (15\%) of ${ }^{14} \mathrm{C}$ into the $22: 0$ fraction in samples from older men (76-86 years) compared to that $(23 \%)$ for younger men (57-65 years). The amount of ${ }^{14} \mathrm{C}$ incorporated into the 20:0 carbon compounds of samples evaluated 0 to $1+$ for spermatogenesis $(20.1 \pm 2.7 \%)$ was less $(P=0.01)$ than that in samples rated $3+$ to $4+(28.5 \pm 1.7 \%)$. The mean value for the samples rated $2+$ was $23.7 \pm$ $2.2 \%$ incorporation. The amount of ${ }^{14} \mathrm{C}$ incorporated into the $22: 0$ carbon compounds of samples rated 0 to $1+$ for spermatogenesis $(30.4 \pm 4 \cdot 1 \%)$ was more than that in samples rated $3+$ to $4+$ $(22 \cdot 8 \pm 2 \cdot 5 \%: P=0 \cdot 14)$, while the value for samples rated $2+$ was $27 \cdot 0 \pm 2 \cdot 0 \%$.

The major incorporation into saturated fatty acids was into palmitic acid, followed by myristic and stearic, and into unsaturated fatty acids was into 20:3 and 22:4 with smaller amounts into 22:2 and $22: 3$. About $60 \%$ of the incorporated ${ }^{19} \mathrm{C}$ was in unsaturated acids. No statistically significant correlation with age or with the spermatogenic rating could be shown for the individual labelled fatty acids.

The distribution of the ${ }^{14} \mathrm{C}$ incorporated into various lipid classes (mean \pm S.E.M., $n=23$ ) was $30 \cdot 3 \pm 1 \cdot 6 \%$ for phospholipids, $15 \cdot 1 \pm 1 \cdot 3 \%$ for triglycerides, $11.6 \pm 1 \cdot 5 \%$ for unesterified fatty acids, $18.4 \pm 1.4 \%$ for unesterified cholesterol, $12.7 \pm 0.6 \%$ for cholesterol esters and $8.5 \pm 0.9 \%$ for diglycerides. There was no detectable pattern related to age. However, the incubations with tissue rated 0 to $1+$ with respect to spermatogenesis ( 8 subjects) had a $22.5 \pm 1.7 \%$ incorporation of the total ${ }^{14} \mathrm{C}$ into the phosphatide fraction compared with $34 \cdot 0 \pm 2 \cdot 1 \%$ incorporation in incubations with tissue (10 subjects) rated $3+$ to $4+$ for spermatogenesis $(P<0.001)$. Incubations of tissues rated $2+(13$ subjects $)$ had a $30.9 \pm 1 \cdot 6 \%$ incorporation.

These results show that human testicular tissue can synthesize fatty acids from $\left[1-{ }^{14} \mathrm{C}\right]$ acetate and can incorporate the synthesized fatty acids into complex lipids. The 20-carbon and 22-carbon unsaturated fatty acids are important in phospholipid formation and were presumably synthesized 
by elongation of endogenous fatty acids with the $\left[1-{ }^{14} \mathrm{C}\right]$ acetate, as is known to occur in rat testicular tissue (Davis \& Coniglio, 1966; Bridges \& Coniglio, 1970a).

Similar results have been reported for rat testicular tissue (Evans et al., 1971) into which about $5 \%$ of the substrate is incorporated/g tissue and about $35 \%$ of the total amount of ${ }^{14} \mathrm{C}$ incorporated is into saturated fatty acids. However, most of the incorporation into unsaturated fatty acid is into $22: 4$ in rat testes and into $20: 3$ in human testes. There is only a trace of $20: 3$ present in rat compared to the $5 \%$ of the total fatty acids in human testicular tissue. The distribution of the incorporated ${ }^{14} \mathrm{C}$ into various lipid classes also differs in human and rat tissue; in rat, there is equal incorporation into phospholipids and triglycerides (30\% each) and almost as much $(25 \%)$ into unesterified fatty acids (Evans et al., 1971).

The results described in these studies in vitro show that extrapolations to man of results obtained in vivo in rats should be limited and cautious.

This work was supported by Research Grant 5 R01 HD06070 from the U.S. Public Health Service.

\section{References}

Bridges, R.B. \& Coniglio, J. G. (1970a) The biosynthesis of $\Delta 9,12,15,18$ tetracosatetraenoic and of $\Delta 6,9,12,15,18$ tetracosapentaenoic acids by rat testes. J. biol. Chem. 245, 46-49.

BRIDGES, R.B. \& CoNiglio, J.G. (1970b) The metabolism of linoleic and arachidonic acids in rat testes. Lipids 5, 628-635.

Coniglio, J. G., Zseltvay, R.R., JR \& Whorton, R.A. (1971) Biosynthesis of stearic acid in rat testes. Biochim. biophys. Acta 239, 374-375.

Coniglio, J.G., Grogan, W.M., JR \& Rhamy, R.K. (1974) Lipids of human testes removed at orchidectomy. J. Reprod. Fert. 41, 67-73.

Coniglio, J.G., Grogan, W.M., JR \& Rhamy, R.K. (1975) Lipid and fatty acid composition of human testes removed at autopsy. Biol. Reprod. 12, 255259.
Davis, J.T. \& Coniglio, J.G. (1966) The biosynthesis of docosapentaenoic and other fatty acids by rat testes. J. biol. Chem. 241, 610-612.

Evans, O.B., JR, Zseltvay, R., Whorton, R. \& Coniglio, J.G. (1971) Fatty acid synthesis in rat testes injected intratesticularly or incubated with $1-{ }^{14} \mathrm{C}$ acetate. Lipids 6, 706-711.

Farquhar, J.W., Insull, W., JR, Rosen, P., Stoffel, W. \& AHRENS, E.M., JR (1959) The analysis of fatty acid mixtures by gas-liquid chromatography. Nutr. Rev. 17, Suppl. 2.

Hall, P.F., Nishizawa, E.E. \& EIr-Nes, K.B. (1963) Synthesis of fatty acids by testicular tissue in vitro. Can. J. Biochem. Physiol. 41, 1267-1274.

Whorton, A.R. \& Coniglio, J.G. (1975) Studies in vitro of lipogenesis in rat testicular tissue. Lipids 10, 783-789. 